\title{
Home range and habitat use of a bearded vulture Gypaetus barbatus L., 1758 along the western border of its Pyrenean distribution area.
}

\section{Área de campeo y uso del hábitat del quebranta- huesos Gypaetus barbatus L., 1758 en el límite occidental de la distribución de la población de Pirineos.}

Juan Arizaga ${ }^{1 *}$, Mikel Olano ${ }^{1,2}$, Javier Vázquez ${ }^{2}$, Alexandra Egunez $^{1}$, Carmelo Fernández $^{3}$, Paz Azkona 4

\begin{abstract}
\footnotetext{
1 Department of Ornithology, Aranzadi Sciences Society Zorroagagaina 11, 20004 Donostia-San Sebastián (Spain).

2 Gipuzkoa Administration

Pza. Gipuzkoa s/n, 20004 Donostia, Spain.

3 External Advisor to the Government of Navarra Castillar 18, 31392 Pitillas (Navarra), Spain.

4 External Advisor to the Government of Navarra Travesía Bayona 1, 31011 Pamplona, Spain.

*Correspondencia: jarizaga@aranzadi.eus
}

The region of Gipuzkoa is used on a permanent basis by the bearded vulture Gypaetus barbatus L., 1758, but the colonization process is slow, apparently due to the difficulty of finding a permanent mate. This article aims to contribute to evaluating the role of Gipuzkoa, which forms the western border of the Pyrenean population of bearded vulture, in the expansion and conservation of the species. We used data from a territorial adult male which was captured and GPS-tracked. GPS data revealed a habitual home range area of $235 \mathrm{~km}^{2}$ within the Aralar mountains and its surroundings, although this bird also made "excursions" to the western-central Pyrenees, probably in search of social interactions. Our results thus suggest that Gipuzkoa presents a good foraging environment although this is offset by a poor, deficient, social environment. Consequently, compared to zones in the eastern Pyrenees, the colonization of Gipuzkoa and other regions along the west of 
the Pyrenees is slow, due seemingly to the very high proportion of transients and the difficulties that settled individuals experience in finding a permanent mate.

Key words: Avian scavengers, GPS-tracking, Pyrenees, raptor conservation, spatial ecology.

\section{Resumen}

Gipuzkoa es una región que cuenta con una presencia constante de quebrantahuesos Gypaetus barbatus L., 1758, pero el proceso de colonización es lento, posiblemente debido a la dificultad de que se consoliden parejas estables. Este artículo pretende contribuir a evaluar el rol de Gipuzkoa, que se sitúa en el borde occidental del área de distribución de la población pirenaica de quebrantahuesos, en la expansión de la especie y su conservación. Para ello se utilizaron los datos que fueron proporcionados por un ave adulta que fue equipado con un GPS. Las localizaciones de este ejemplar dieron un área de campeo de $235 \mathrm{~km}^{2}$, coincidente en su mayor parte con las montañas de Aralar, si bien este ejemplar también realizó algunas "excursiones" al sector centro-occidental de los Pirineos, probablemente en busca de interacciones sociales. Nuestros resultados sugieren que Gipuzkoa ofrece buenas condiciones ambientales para la especie, si bien el ambiente social es deficiente. En consecuencia, y en comparación con otras zonas del Pirineo, la colonización de Gipuzkoa y otras zonas marginales al área de distribución de la especie en el Pirineo es lenta, posiblemente debido a la gran proporción de aves transeúntes y la dificultada de que se asienten aves maduras experimentadas capaces de establecer parejas sólidas y permanentes.

Palabras clave: Necrófagas, GPS, Pirineos, conservación de rapaces, ecología espacial.

\section{Laburpena}

Gipuzkoako eremuan Gypaetus barbatus L., 1758 ugatzen populazio egonkorra bizi da, baina kolonizazio prozesua motel doa, agian bikote iraunkorrak egonkortzeko zailtasunagatik. Gipuzkoa Pirinioetako ugatzen populazioaren banaketari dagokionez mendebaldeko ertzean kokatzen delarik, artikulu honek herrialdeak zer rol duen ebaluatzen lagundu nahi luke, espeziearen zabalkundean eta iraupenean. Xede horretarako ale heldu batek eskainitako datuak baliatu dira, zeinari GPS bat atxiki zitzaion. Hegazti horren lokalizazioen emaitza 235235 km² -ko eremu bat izan zen, gehiena zuzenki lotuta Aralarreko mendiekin, nahiz eta hegaztiak "ateraldi" batzuk ere egin zituen Pirinioetako erdi-mendebalderantz, ziurrenik kideekin interakzio bila. Gure emaitzek iradokitzen dutenez, Gipuzkoak ingurune baldintza onak ditu espeziearentzat, baina ingurune soziala eskasa da. Ondorioz, eta Pirinioetako beste eremu batzuekin alderatuta, Gipuzkoako kolonizazioa edota espeziearen banaketako beste bazter eremu batzuetakoa geldoa da, agian paseko hegazti proportzio handiagatik eta hegazti helduak bertan kokatzeko zailtasunagatik, ale eskarmentukoak, bikote egonkorrak eta iraunkorrak sortzeko gai direnak.

Gako hitzak: Nekrofagoak, GPS, Pirinioak, harrapakarien kontserbazioa, eremuen ekologia. 


\section{Introduction}

The border of a species' distribution range plays a crucial role during its growth processes, promoting the expansion and colonization of new areas. Understanding how these new zones are used has direct implications from a conservation perspective and helps us to comprehend the mechanisms that drive colonization processes (Duriez et al., 2005, Arroyo \& Razin, 2006, Margalida et al., 2008).

The bearded vulture Gypaetus barbatus L., 1758 is one of the most threatened bird species in the EU, with fewer than 200 adult breeding pairs (Margalida et al., 2008). The Pyrenees ( $n=130$ pairs) hosts ca. $90 \%$ of the EU population (Margalida et al., 2016). The Basque mountains, in northern Iberia, and specifically the province of Gipuzkoa along the western edge of the Pyrenean distribution area of bearded vulture, could potentially be colonized by the species and thus be an area of key importance in connecting the Pyrenean population with the recent settlement of this species in the Cantabrian mountains (the result of a still ongoing reintroduction program) (Báguena et al., 2007).

Recently, and following an increase in the Pyrenean population and the expansion of its distribution range (Gómez de Segura et al., 2012), there has been an increasing number of sightings of individuals in areas close to the original distribution range, where the species had rarely been seen previously (Aierbe et al., 2002, Margalida et al., 2016). With the aim of assessing the potential role of Gipuzkoa for the bearded vulture and its conservation, we provide herewith an analysis of data from the first adult individual to settle in Gipuzkoa, which was caught and tagged with a GPS device in order to describe its spatial ecology, to determine which zones are key for its conservation and to evaluate the role of this province in the expansion process of the Pyrenean population of bearded vulture.

\section{Material and methods}

\section{Study area}

This study was carried out in the province of Gipuzkoa. It is a mountainous area of ca. $2000 \mathrm{~km}^{2}$ with a maximum altitude of $1551 \mathrm{~m}$ a.s.I. The most important mountain ranges are situated in the east and south of the province and all of them are included in the Natura 2000 network (for details see Fig. 1). The amount of livestock is very high considering the size of the province $(200,000$ head -of which 143,000 are sheepwhich gives rise to an average density of 100 head of livestock $/ \mathrm{km}^{2}$; source: Basque Government). The landscape is composed of a mosaic of woodland (mostly native forest of oaks or beech or exotic pine plantations) and meadows, the latter being particularly abundant in mountainous areas ranging between $800-1000 \mathrm{~m}$ a.s.l. 


\section{GPS-tag data}

This study uses data from a GPS-tagged individual (called "Kiriku") caught in Aralar, a mountain range situated in SE Gipuzkoa. This bird is a male hatched in 2006 in Navarra, which was ringed in the nest with both Darvic PVC (6PM) and metal rings, as well as wing-tags. This bird was seen repeatedly in the Pyrenees (Gil et al., 2010) and, thereafter, in Aralar, where we found that it seemed to have been recruited, at a distance of $80 \mathrm{~km}$ from its birth place. Kiriku was caught at a feeding station in March 2015, and then equipped with a GPS-device (model: PTT-100/Solar Argos, Microwave Ltd., $70 \mathrm{~g}$ in weight) fitted with a hand-made Teflon backup harness (Garcelon, 1985). Data (the exact geographic point) were collected every two hours from 08:00 to 18:00 in autumn-winter, and from 08:00 to 22:00 in spring-summer. The device also recorded the bird's altitude and whether it was moving or stationary, as well as its speed and track direction in the case of the latter.

GPS data were analysed using GIS tools in the software QGIS. Home range areas were calculated using a number of statistical approaches: minimum convex polygon, and 90\% and 50\% kernel area. To assess the bird's habitat use, the EUNIS vegetation cover database for the Basque Country and Navarra was used. The original vegetation cover categories used in the database were collapsed into only 7 categories: PAST, pastures; FORE, native forest; PLAN, exotic tree plantation (mostly of Monterey pine; Olano et al., 2016a); ROCK, rocky areas; URBA (urban areas, including roads and paths); MOOR, moorland, as well as other shrubby areas; REST, other habitat types.

\section{Results}

Overall, the GPS provided data from 01 April 2015 to 19 February 2016 (when the harness broke and the device was retrieved). During this 11 month period, we obtained 883 positions, $713(80.7 \%)$ of which were during the day and $170(19.3 \%)$ at night. Of those obtained during the day, $554(77.7 \%)$ corresponded to the bird being on the ground and 159 (22.3\%) when it was in flight.

Looking at the data by region, most (68.4\%) locations were situated in the neighboring province of Navarra, followed by Gipuzkoa (24.5\%), with the majority in fact being along the border of the two provinces (Fig. 1). The remaining locations were sited in Huesca province (5.2\%) and France (1.8\%), as well as Zaragoza province (0.1\%) (Fig. 1). In total, $86 \%(n=762)$ of all locations were obtained within the Aralar Natura 2000 site.

The global minimum convex polygon (MCP) resulted in an area of 7,952 $\mathrm{km}^{2}$ (Fig. 1), extending from Aralar in SE Gipuzkoa to the Pyrenees and the pre-Pyrenean mountain 


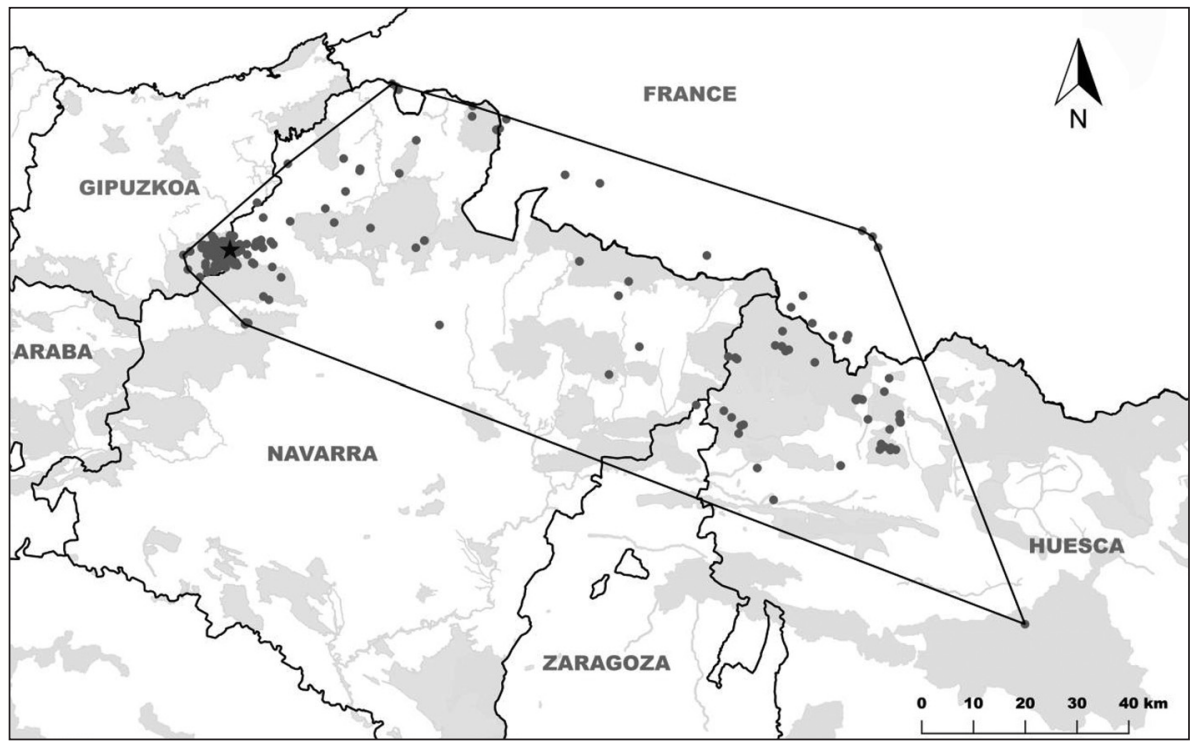

Fig. 1.- Locations (dark grey dots) provided by Kiriku from April 2015 to February 2016 and the corresponding minimum convex polygon. Pale grey-shaded polygons indicate Natura 2000 sites. The black star shows the global centroid position.

Fig. 1.- Localizaciones (puntos en gris) proporcionadas por Kiriku entre abril de 2015 y febrero de 2016, y el correspondiente polígono convexo mínimo. Las superficies en gris claro indican lugares Natura 2000. La estrella negra señala la localización del centroide.

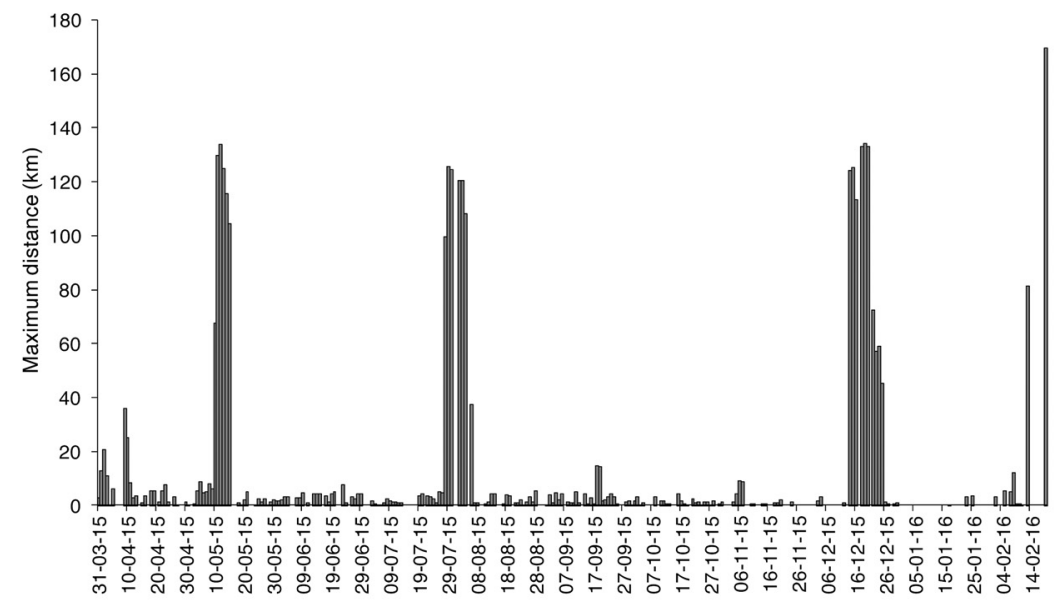

Fig. 2.- Maximum distance at which Kiriku was recorded each day in relation to the global centroid position (situated in Aralar mountains; Fig. 1).

Fig. 2.- Distancia máxima diaria a la que Kiriku fue observado en relación a la posición del centroide (localizado en Aralar; Fig. 1). 


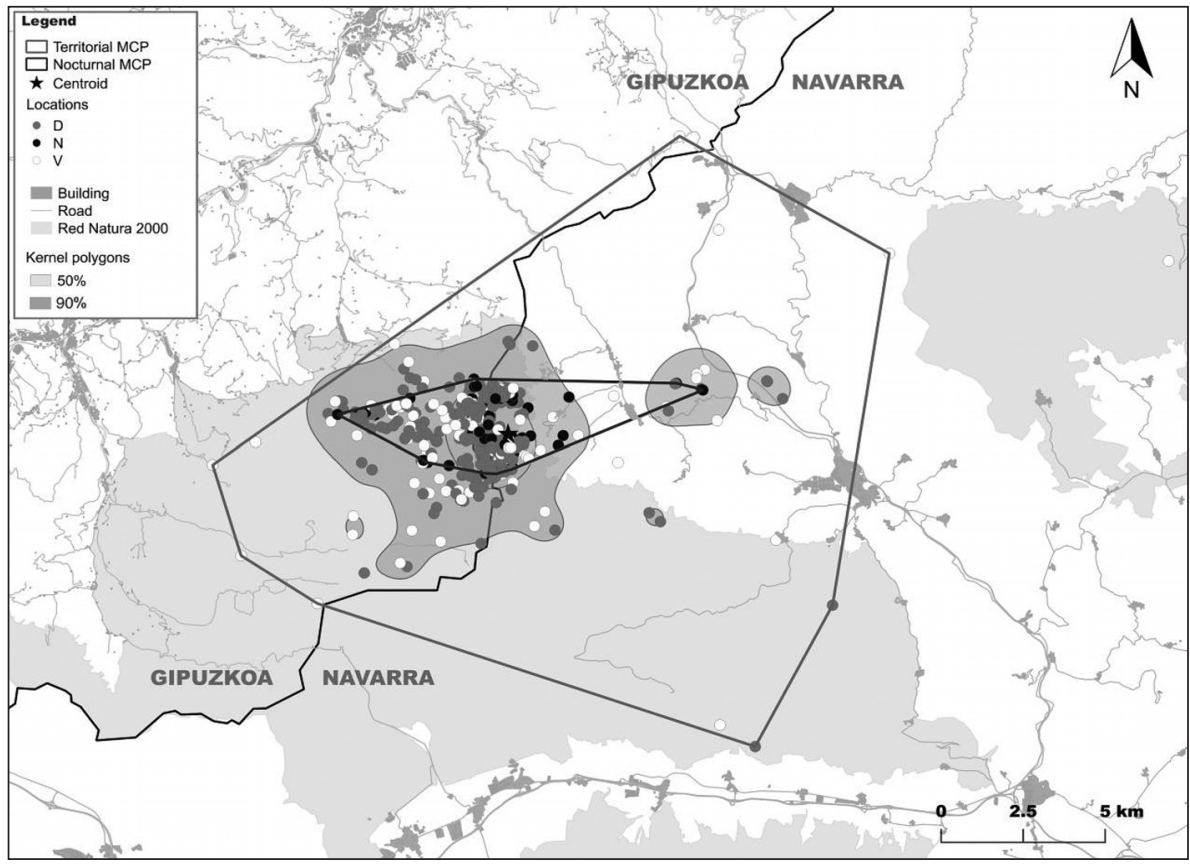

Fig. 3.- The minimum convex polygon (grey line) represented by those locations found at a distance less than $15 \mathrm{~km}$ from the centroid of the global minimum convex polygon (represented by a star). The (smaller) minimum convex polygon represented by a dark line refers to night locations. Dots represent locations in flight (white) or on the ground, either at night or during the day (black and grey, respectively). Pale grey-shaded polygons indicate Natura 2000 sites.

Fig. 3.- Polígono mínimo convexo representado por las localizaciones obtenidas a distancias inferiors a $15 \mathrm{~km}$ del centroide que se presenta con una estrella. El polígono mínimo convexo más pequeño representa las localizaciones que se obtuvieron de noche. La coloración de los puntos indica si Kiriku estaba posado en el suelo de noche (puntos negros), de día (puntos grises) o volando (puntos en blanco). Las superficies en gris claro indican lugares Natura 2000.

ranges in Huesca. This global MCP, however, was strongly influenced by a number of locations situated extremely far from the habitual home range area in Aralar. Locations situated more than $15 \mathrm{~km}$ from the global MCP centroid were produced over very specific short periods of time (Fig. 2), in what could be called extra-territorial movements (hereafter, excursions). If the locations at $>15 \mathrm{~km}$ from the centroid are excluded, however, an MCP of $235 \mathrm{~km}^{2}$ is obtained (hereafter, home range area) which accounts for $3 \%$ of global MCP (Fig. 3).

When excursions were excluded, night locations were found to be within a radius of $<7 \mathrm{~km}$ from the global centroid, thus nocturnal MCP comprised an area of $18.4 \mathrm{~km}^{2}$, i.e. $7.8 \%$ of the home range area (Fig. 3). Furthermore, night locations beyond 


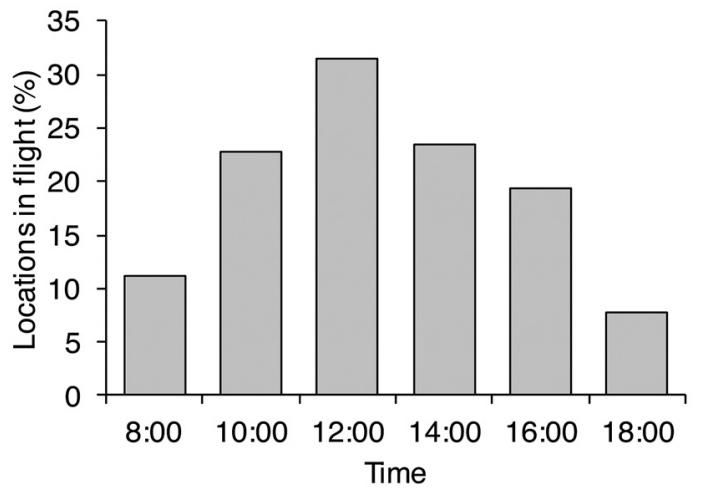

Fig. 4.- Hourly distribution of the locations in flight.

Fig. 4.- Distribución de localizaciones en vuelo por horas. a $3.5 \mathrm{~km}$-radius were in fact rather scarce $(11 \%)$, and most were rarely used more than once, suggesting that they were occasional roosting places.

Overall, we detected 7 excursions, which comprised three short-range trips $(<50 \mathrm{~km}$ from the centroid in Aralar), and four of longer distances (>100 km) (Annex I). The short-range excursions involved distances of (1) $20.8 \mathrm{~km}$ (a 2-day trip made by Kiriku

to a mountainous area in northern Navarra); (2) $36 \mathrm{~km}$ (another 2-day trip, also to northern Navarra); and (3) $15 \mathrm{~km}$ (a 2-day trip, to a mountain range situated south of Aralar). The longer excursions comprised (1) a trip of 6 days, up to Canfranc valley (Huesca, central-western Pyrenees; maximum, $134 \mathrm{~km}$ ); (2) a second trip of 9 days up to Ansó valley (also in Huesca; maximum, $126 \mathrm{~km}$ ); (3) a trip of 12 days, also to Ansó valley (Huesca; maximum, 134 km); (4) a final trip taking in Sierra de Guara (Huesca; maximum, $170 \mathrm{~km}$ ), where the GPS was lost on 19 February. On these long-range trips, Kiriku used some kind of corridor across northern Navarra (i.e., through the western Pyrenees and the southern Pyrenean foothills).

Kiriku spent ca. $22 \%$ of the daylight period flying (18\% if the night period is also included -i.e. over a $24 \mathrm{~h}$ period). The bird spent the greatest proportion of time in flying at around midday (Fig. 4), with flight speeds ranging from 8 to almost $60 \mathrm{~km} / \mathrm{h}$ (mean \pm SD: $22.6 \pm 7.4 \mathrm{~km} / \mathrm{h}, n=124$ ), and altitudes varying from $530 \mathrm{~m}$ to 2,810 $\mathrm{m}$ above sea level (mean: 1,182 $\pm 284 \mathrm{~m}$ ). It should be noted that in Aralar the highest peak is $1,431 \mathrm{~m}$ above sea level.

Regarding habitat use, the $90 \%$ kernel polygons revealed differences in use depending on bird behaviour and activity (Fig. 5). The most used habitat type in terms of all recorded positions and for on-ground positions during the day was pasture, while those correlating to night locations or when the bird was in flight were mostly associated with native forest. The $50 \%$ kernel polygons, however, provided a different figure (Fig. 5), whereby there was similar use made of pasture, moorland and forest when considering on-ground positions during the day and in terms of all recorded positions, while positions at night or in flight were mostly associated with moorland. 

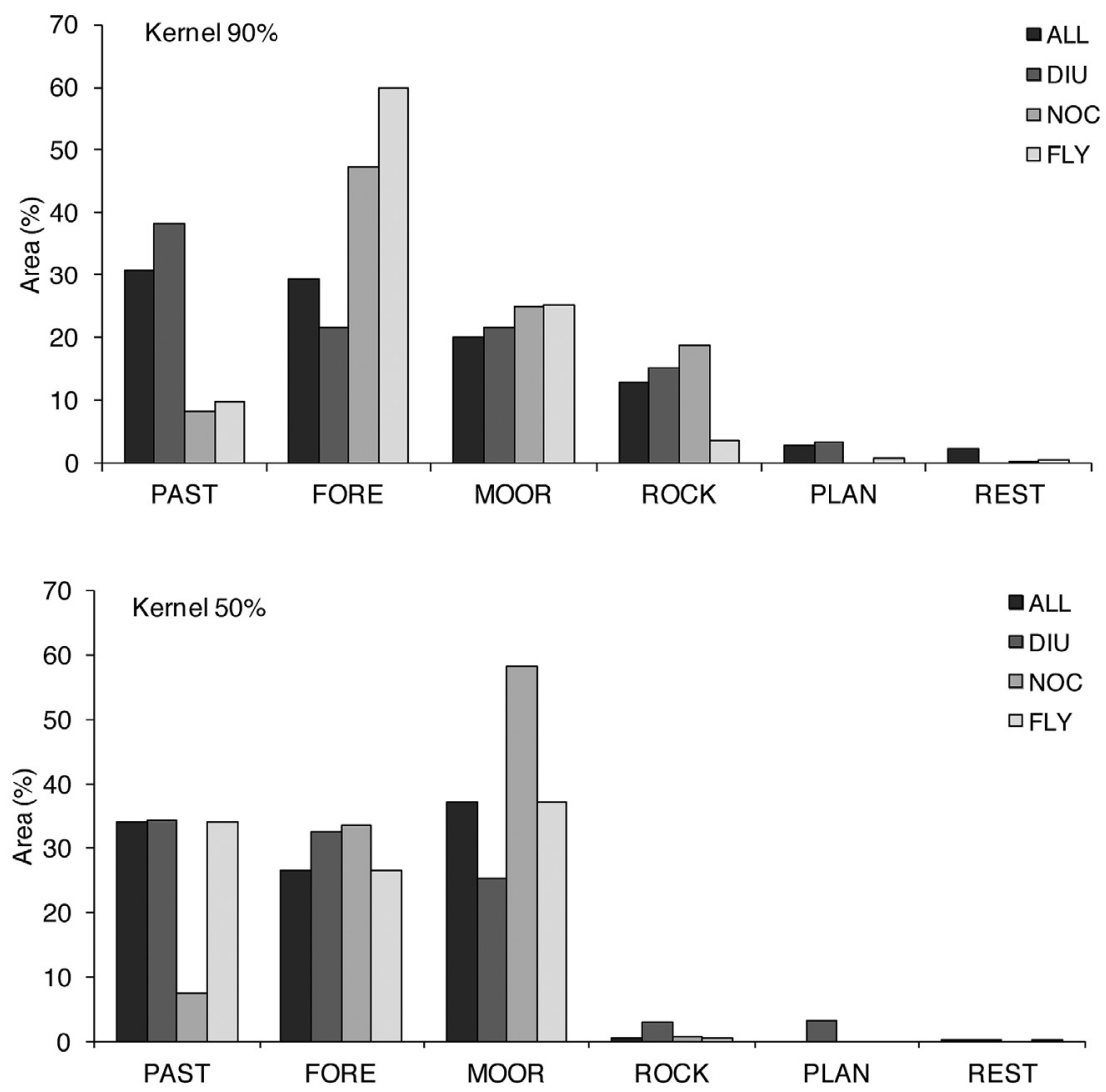

Fig. 5.- Habitats used by Kiriku in terms of the $90 \%$ and $50 \%$ kernel polygons after excluding positions corresponding to excursions. Abbreviations: PAST, pastures; FORE, native forest; PLAN, tree plantation (mostly consisting of Monterey pine plantations); ROCK, rocky areas; MOOR, moorland, shrubs; REST, other habitat types.

Fig. 5.- Hábitats utilizados por Kiriku a partir de polígonos kernel al $90 \%$ y 50\%, una vez excluidas las posiciones de las excursiones. Abreviaturas: PAST, pastos; FORE, bosque nativo; PLAN, plantación forestal (pino de Monterey, principalmente); ROCK, roquedos; MOOR, zona arbustiva, brezal, argomal; REST, otro tipo de hábitats.

\section{Discusions}

The data provided by Kiriku revealed a relatively small home range area mostly situated within Aralar. This behavior is typical of adult territorial birds (Margalida et al., 2016), which would indicate that the area is suitable for breeding. It is worth noting that in 2016 Kiriku did find a mate, and was even found to have built a nest, although in the end the pair did not lay eggs. 
As expected, Kiriku was observed mostly in places rich in pastures, where it would have been looking for food resources. Gipuzkoa is plentiful in this respect, with Aralar alone estimated to host $>30,000$ head of livestock and it is worth noting that, in this scenario, the grazing of livestock in the mountains of Gipuzkoa plays a considerable role in the conservation of bird scavengers (Olano et al., 2016b), including the bearded vulture. With an altitude below 1,600 m, Gipuzkoa is mostly covered by forests, so the presence of vultures and other scavenger birds in this region is strongly associated with livestock farming in mountain pastures. Another point would be to determine to what extent such mountain pastures would also exist in a previous scenario potentially hosting wild ungulates.

Kiriku made four long trips to visit the central-western Pyrenees and the southern prePyrenean mountain ranges in Huesca. During these trips, lasting less than 10 days, the bird visited several places with currently occupied bearded vulture territories (Margalida \& Heredia, 2005), as well as some supplementary foraging points (places set up specifically to improve the foraging environment of the species). However, it is unlikely that Kiriku made these trips just to look for food, due to the high quantity of food existing in Aralar, where there has also been a supplementary foraging station in place since 1997. This suggests that these long trips were based on a social demand. Up until 2016, Kiriku had mated with other visiting females which, however, left the area before trying to breed. This social instability likely forced Kiriku to visit previously known regions which were rich in conspecifics, during which time he would have been trying to attract a mate to his territory and/or settle, if there was availability, in one such new territory. Supporting this hypothesis we found that after the trip made on December of 2015, Kiriku was seen with a mate, a subadult female that remained with him for 3 months, up to April 2016, when she was ousted by the female that finally tried to breed with Kiriku in 2017.

Adult bearded vultures exploit much smaller areas than their non-breeding, juvenile or immature conspecifics (López-López et al., 2013, Gil et al., 2014, Margalida et al., 2016). The global MCP used by Kiriku (ca. 8,000 km²), however, was not much smaller than the mean area reported for immature bearded vultures in the Pyrenees -ca. $12,000 \mathrm{~km}^{2}$ - (Gil et al., 2014), although it was considerably smaller than that reported for one juvenile in southern Africa -38,500 km²- (Urios et al., 2010). However, Kiriku performed some exceptional long excursions, that clearly influenced our MCP estimation. By removing these excursions, the MCP was reduced to $235 \mathrm{~km}^{2}$, a value which is within the range found for adult birds in other populations (e.g., Gavashelishvili \& McGrady, 2007).

Our results probably indicate that Gipuzkua provides a good foraging environment but a poor or deficient social environment. Situated within the borders of the distribution area of the Pyrenean population, Aralar can be assumed to be visited by a relatively high number of individuals, although, however, they likely remain within the 
zone for only very short periods. As compared to other zones across the eastern Pyrenees (A. Margalida, com. pers.), the colonization of Gipuzkoa and other regions along the west of the Pyrenees is relatively slow. The reasons for this phenomenon have been set out briefly above: with a very high proportion of transients, settled individuals like Kiriku seem to experience problems in finding a permanent mate.

\section{Acknowledgements}

This study was funded by the Gipuzkoa Administration and the Biodiversity Conservation Service of the Navarra Government (GPS-tracking). We are grateful to V. García (MAGRAMA), F. Díez and I. Mendiola, for their help in the field and support.

\section{References}

Aierbe, T., Olano, J.M., Vázquez, J. 2002. Situación actual de las poblaciones de los necrófagos Buitre leonado (Gyps fulvus), Alimoche Común (Neophron percnopterus) y Quebrantahuesos (Gypaetus barbatus) en Gipuzkoa. Munibe, Cienc. nat.53: 211-228.

Arroyo, B., Razin, M. 2006. Effect of human activities on bearded vulture behaviour and breeding success in the French Pyrenees. Biol. Conserv. 128: 276-284.

Báguena, G., Sánchez-Castilla, E., Antor, R.J. 2007. Criterios para la reintroducción de una especie amenazada: el quebrantahuesos en el Parque Nacional de los Picos de Europa. Organismo Autónomo Parques Nacionales. Madrid.

Duriez, O., Eraud, C., Barbraud, C., Ferrand, Y. 2005. Factors affecting population dynamics of Eurasian woodcocks wintering in France: assessing the efficiency of a hunting-free reserve. Biol. Conserv. 122:89-97.

Garcelon, D.K. 1985. Mounting backpack telemetry on Bald Eagles. Institute for Wildlife Studies Arcata, California, USA.

Gavashelishvili, A., McGrady, M.J. 2007. Radio-satellite telemetry of a territorial bearded vulture Gypaetus barbatus in the Caucasus. Vulture News 56:4-13.

Gil, J.A., Báguena, G., Sánchez-Castilla, E., Antor, R.J., Alcántara, M., López-López, P. 2014. Home ranges and movements of non-breeding Bearded Vultures tracked by satellite telemetry in the Pyrenees. Ardeola 61: 379-387.

Gil, J.A., Díez, O., Báguena, G., Lorente, L., Pérez, C., Losada, J.A., Alcántara, M. 2010. Dispersión juvenil del Quebrantahuesos (Gypaëtus barbatus) en los Pirineos (España-Francia). Fundación para la Conservación del Quebrantahuesos - Gobierno de Aragón. Zaragoza. 
Gómez de Segura, A., Martínez, J.M., Alcántara, M. 2012. Population size of the endangered Bearded Vulture Gypaetus barbatus in Aragón (Spain): an approximation to the Pyrenean population. Ardeola 59: 43-55.

López-López, P., Zuberogoitia, Í., Alcántara, M., Gil, J.A. 2013. Philopatry, natal dispersal, first settlement and age of first breeding of bearded vultures Gypaetus barbatus in central Pyrenees. Bird Study 60: 555-560.

Margalida, A., Heredia, R. 2005. Biología de la conservación del quebrantahuesos Gypaetus barbatus en España. Organismo Autónomo de Parques Nacionales. Madrid.

Margalida, A., Heredia, R., Razin, M., Hernández, M. 2008. Sources of variation in mortality of the Bearded Vulture Gypaetus barbatus in Europe. Bird Conserv. Int. 18:1-10.

Margalida, A., Pérez-García, J.M., Afonso, I., Moreno-Opo, R. 2016. Spatial and temporal movements in Pyrenean bearded vultures (Gypaetus barbatus): integrating movement ecology into conservation practice. Scientific Reports 6: 35746.

Olano, M., Beñaran, H., Laso, M., Arizaga, J. 2016a. Exotic pine plantations and the conservation of the threatened Red Kite Milvus milvus in Gipuzkoa, Northern Iberia. Ardeola 63: 369-374.

Olano, M., Vazquez, J., Aierbe, T., Ansorregi, F., Galdos, A., Ugarte, J., Hurtado, R., Beñaran, H., Urruzola, A., Arizaga, J. 2016b. Distribución, tendencia poblacional y parámetros reproductivos del Buitre leonado Gyps fulvus y del Alimoche Neophron percnopterus en Gipuzkoa. Revista Catalana d'Ornitología 32: 20-29.

Urios, V., López-López, P., Limaña, R., Godino, A. 2010. Bearded Vulture (Gypaetus barbatus meridionalis) in South Africa revealed by GPS satellite telemetry. Ornis Fenn. 87: 114-118. 